\title{
Stocking density, milking duration, and lying times of lactating cows on Canadian freestall dairy farms
}

\author{
G. L. Charlton, ${ }^{* 1}$ D. B. Haley, $\dagger$ J. Rushen, ${ }^{*}$ and A. M. de Passillé ${ }^{\star}$ \\ ${ }^{*}$ Pacific Agri-Food Research Centre, Agriculture and Agri-Food Canada, Agassiz, British Columbia, Canada, V0M 1A0 \\ †Department of Population Medicine, University of Guelph, Guelph, Ontario, Canada, N1G 2W1
}

\begin{abstract}
Lying time is an important measure of cow comfort, and the lying behavior of dairy cattle can now be recorded automatically with the use of accelerometers. To assess the effect that stall stocking density and the time that cows spend away from the home pen being milked has on the lying behavior of Holstein cattle, a total of 111 commercial freestall dairy farms were visited in Canada. Accelerometers were used to automatically record the lying behavior of 40 focal cows per farm. Total duration of lying, lying bout frequency, and the mean duration of lying bouts were calculated. Pen population was the total number of cows in the pen. To calculate stall stocking density (\%) the number of cows in the pen and the number of useable stalls were counted and multiplied by 100 , and the length $\times$ width of the pen was divided by the number of cows in the pen to calculate area/cow $\left(\mathrm{m}^{2}\right)$. Time away from the pen per day was recorded from when the first cow in each pen was taken out of the home pen for milking until the last cow returned to the home pen after milking, and this time was multiplied by daily milking frequency. The median value for lying duration at the farm level was $10.6 \mathrm{~h} / \mathrm{d}$, with 10.5 lying bouts/d, and a median lying bout duration of $1.2 \mathrm{~h}$. Stall stocking density ranged from 52.2 to $160.0 \%$, with very few farms $(7 \%)$ stocking at greater than 120\%. Although stall stocking density was not significantly correlated with lying behavior, the results showed that no farm with stocking density greater that $100 \%$ achieved an average herd lying duration of 12 $\mathrm{h} / \mathrm{d}$ or higher, whereas $21.6 \%$ of farms with a stocking density of $100 \%$ or less did achieve the target lying time of $\geq 12 \mathrm{~h} / \mathrm{d}$, as recommended by the Canadian Code of Practice $\left(\chi^{2}=4.86\right.$, degrees of freedom $\left.=1\right)$. Area $/$ cow $\left(\mathrm{m}^{2}\right)$ was not correlated with any aspect of lying behavior, but regardless of space per cow, pen population was correlated with daily frequency and duration of lying
\end{abstract}

Received April 15, 2013

Accepted January 6, 2014.

${ }^{1}$ Corresponding author: gemmacharlton1@gmail.com bouts. As the number of cows in the pen increased, lying daily bout frequency increased (correlation coefficient $=0.24$ ) and lying bout duration decreased (correlation coefficient $=-0.30$ ). Lying behavior was affected by the time the cows were away from the pen being milked. When cows were away from the pen for longer than $3.7 \mathrm{~h} / \mathrm{d}$, no farm achieved the recommended herd median lying time of $12 \mathrm{~h} / \mathrm{d}$ or longer. These results suggest that providing 1 stall for each cow in the pen and minimizing time away from the pen are important factors if cattle are to achieve the recommended daily lying duration of $12 \mathrm{~h} / \mathrm{d}$.

Key words: dairy cow, lying time, stocking density, milking time

\section{INTRODUCTION}

The time cows spend lying down is an important measure of cow comfort (EFSA, 2009b; von Keyserlingk et al., 2009). Reducing the time that cattle can lie down results in both behavioral and physiological evidence of stress (Munksgaard and Simonsen, 1996) and short lying times are a risk factor for lameness (Cook et al., 2004; Bell et al., 2009; Chapinal et al., 2009; Proudfoot et al., 2010). Research into the motivation of cows to lie down show that this is a high-priority behavior (Metz, 1985; Munksgaard et al., 2005) and that cows are motivated to spend around $13 \mathrm{~h} / \mathrm{d}$ lying down (Jensen et al., 2005). Small-scale experimental studies find that cows in freestalls spend an average of around $12 \mathrm{~h} / \mathrm{d}$ lying down (EFSA, 2009b). Cattle welfare standards are now beginning to address the issue of lying time in dairy cows. The Canadian Code of Practice (Dairy Farmers of Canada, 2009) is a set of guidelines for the welfare of dairy cattle in Canada, which includes requirements and recommended best practices for the care and handling of dairy cattle that are expected to be implemented by all Canadian dairy farmers. This Code recommends that stalls be designed so that cows can lie down for $12 \mathrm{~h} / \mathrm{d}$.

The time cattle spend lying down can be measured automatically using accelerometers (Ledgerwood et al., 2010; Rushen et al., 2012) in a time-efficient manner 
(Ito et al., 2009; von Keyserlingk et al., 2012; Deming et al., 2013) and with high validity (Ledgerwood et al., 2010). Large-scale studies using this technology on commercial freestall farms in North America report large differences between farms in herd lying time, with most farms having a herd mean lying time less than 12 h/d (Ito et al., 2009; USDA, 2010; von Keyserlingk et al., 2012), although Gomez and Cook (2010) reported herd mean lying times closer to $12 \mathrm{~h} / \mathrm{d}$.

Although most dairy farm animal welfare standards are still reliant on resource-based criteria, such as recommended stall stocking densities, there is increased interest in being able to assess the outcomes or the consequences of these for the animals (Rushen et al., 2011). Both the stall stocking density (defined as the number of cows per 100 lying stalls) and the time away from the home for milking are likely to affect the time cows lie down and may be responsible for some of the variation between farms in mean herd lying time. The European Food Safety Authority (Parma, Italy) recently concluded that overstocking was one of the most serious risks to the welfare of cattle in freestall housing (EFSA, 2009a). Small-scale, experimental studies have shown that the time cows lie down is reduced by high stocking density (Fregonesi et al., 2007; Krawczel et al., 2012; Telezhenko et al., 2012) and time spent away from the home pen for milking (Botheras, 2006; Gomez and Cook, 2010), but only a few studies have examined these relationships on commercial farms. Bach et al. (2008) found lower milk production on farms with fewer stalls per cow, but Chapinal et al. (2013) did not find that overstocking was a risk factor for lameness. It seems likely that stocking density and time for milking would interact, as competition for lying stalls would be higher if fewer stalls were available and if less time were available to lie down, but this interaction has not been studied in detail. Although dairy producers are often advised to keep stocking density below $120 \%$ (e.g., Dairy Farmers of Canada, 2009), overstocking is commonly found on commercial dairy farms in the United States (USDA, 2010; von Keyserlingk et al., 2012).

Our objectives were to describe the lying times of cows, and the stall stocking density (\%), pen population size (number of cows in the pen), area/cow $\left(\mathrm{m}^{2}\right)$, and time away from the home pen for milking $(\mathrm{h} / \mathrm{d})$ on commercial freestall farms in Canada and to investigate how these variables might correlate with the lying behavior of dairy cattle. We hypothesized that time cows spent lying down would be lower with higher stall stocking densities and longer times away from the pen and that an interaction would exist between stocking density and milking time.

\section{MATERIALS AND METHODS}

\section{Farm Selection and Description}

Between April 2011 and May 2012, commercial freestall dairy farms in Alberta $(\mathrm{n}=51)$, Ontario $(\mathrm{n}=$ $40)$, and Quebec $(\mathrm{n}=20)$ were visited (Table 1). Farms had to be enrolled in a milk-recording scheme and have mostly Holstein cows, mean milk production above $7,000 \mathrm{~L} /$ cow per year, a herd size of at least 40 lactating cows, and a milking system that had been in use for a minimum of 1 yr. For purposes of another study, the herds were selected to have variation in average cow longevity as measured by the percentage of cows in third lactation or higher and the annual farm percentage turnover rate (Table 1). Letters were sent to farms meeting these criteria, inviting them to participate in the study. The number of letters sent out was based on an expected positive response rate of $20 \%$. Those interested and willing to participate in the study were then contacted by telephone and interviewed. Farms were excluded from the study if they had a management system that allowed lactating cows access to pasture.

\section{Data Collection}

Each farm was visited twice, with an interval of 5 to $10 \mathrm{~d}$, by 2 or more trained team members. Data were collected on 40 lactating Holstein dairy cows from each herd $[\mathrm{DIM}($ mean $\pm \mathrm{SD})=156.0 \pm 95.7$; range $=4$ to 735 ; parity range $=1$ to 12 , with $36 \%$ primiparous]. The cows chosen were those earliest in lactation and with the same ratio of primiparous to multiparous as the farm as a whole. On 63 farms, the 40 focal cows were in a single pen, on 43 farms they were spread across 2 pens, and on 5 farms in 3 pens. We use the term pen to refer to the area containing the focal cows, which might be an enclosed building or a compartment within a building. Each pen $(\mathrm{n}=164)$ was scored for stall stocking density (\%), pen population (number of cows in the pen), area/cow $\left(\mathrm{m}^{2}\right)$, and time away from the home pen for milking $(\mathrm{h} / \mathrm{d})$.

On average, stall width was $116 \mathrm{~cm}( \pm 5.90 \mathrm{~cm}$; range $=104-137 \mathrm{~cm}$ ) and average stall length was $240 \mathrm{~cm}$ $( \pm 17.67 \mathrm{~cm} ;$ range $=207-314 \mathrm{~cm})$. Mattresses made up the most common stall base type (60\%), followed by concrete $(14 \%)$, sand $(13 \%)$, rubber mat $(8 \%)$, waterbed $(4 \%)$, and dirt (1\%). Wood shavings was the most common bedding type (37\%), followed by sawdust (25\%), straw (24\%), sand (10\%), and compost (3\%), and $2 \%$ of farms had no bedding.

To calculate stall stocking density (\%) the number of cows was divided by the number of useable lying stalls and multiplied by 100 . The total number of cows 
Table 1. Median, 25th and 75th percentiles, and range for herd size, cows in third lactation or greater, ${ }^{1}$ annual turnover, ${ }^{1}$ cows culled at $<60$ DIM, ${ }^{2}$ DIM, ${ }^{3}$ parity, ${ }^{3}$ and percentage of primiparous cows ${ }^{3}$ on 111 freestall farms

\begin{tabular}{lccrrr}
\hline Item & Minimum & $\begin{array}{c}25 \text { th } \\
\text { percentile }\end{array}$ & Median & $\begin{array}{c}\text { 75th } \\
\text { percentile }\end{array}$ & Maximum \\
\hline Herd size (no. of cows) & 40.0 & 90.0 & 119.0 & 160.0 & 470.0 \\
Cows in Zthird lactation (\%) & 22.0 & 32.0 & 37.0 & 40.0 & 60.0 \\
Annual turnover (\%) & 21.0 & 32.0 & 38.0 & 24.0 & 59.0 \\
Cows culled at <60 DIM (\%) & 3.0 & 9.0 & 16.0 & 28.8 & 73.0 \\
Average DIM & 37.6 & 76.8 & 98.3 & 125.6 & 249.5 \\
Average lactation & 1.4 & 2.0 & 2.3 & 2.5 & 3.4 \\
Primiparous cows (\%) & 15.0 & 32.5 & 40.0 & 47.5 & 80.0 \\
\hline
\end{tabular}

${ }^{1}$ Mean of years 2008, 2009, and 2010.

${ }^{2}$ Based on 2010 data.

${ }^{3}$ At time of visit.

in each pen containing focal cows was counted (pen population), and these numbers were confirmed with the herd manager during a questionnaire. To determine area/cow $\left(\mathrm{m}^{2}\right)$, the total length $\times$ the width of the pen was divided by the pen population. The time the cows spent away from their home pen being milked $(\mathrm{h} / \mathrm{d})$ was recorded from when the first cow in each pen was taken out of the home pen for milking until the last cow returned to the home pen after milking. Time away from the pen was recorded for the morning milking, and was multiplied by daily milking frequency, which was obtained during a questionnaire with the herd manager.

To record the time the cows spent lying down, accelerometers (HOBO Pendant G Acceleration Data Loggers; Onset Computer Corp., Pocasset, MA) were attached to the hind leg of each cow using Vet-Wrap (CoFlex; Andover Coated products Inc., Salisbury, MA). They were programmed to record the position of the cow (lying or standing) at 1-min intervals for 4 consecutive 24-h periods (Vasseur et al., 2012). Recording was set to begin at $2350 \mathrm{~h}$ on the day of the first farm visit. During the second farm visit, all of the data loggers were removed and the data were downloaded.

\section{Data Analysis}

From the accelerometer data, we calculated the total duration of lying time, lying bout frequency $(/ 24$ $\mathrm{h}$ ), and the mean duration of lying bouts for each focal cow, and we averaged these over the 4-d period. From this, we calculated the mean daily duration of lying down $(\mathrm{h} / \mathrm{d})$, daily frequency of lying bouts, and mean duration of lying bouts for each farm. Spearman rank coefficients of correlation were used to test the correlations between the pen measures (stall stocking density, pen population, area per cow, and time away from the pen) and the measures of time spent lying down were done using $\mathrm{R}$ i386 software (package ver- sion 2.15.1; R Foundation for Statistical Computing, Vienna, Austria). One farm had an extreme stall stocking density of $160 \%$, so this farm was also removed from the analysis. In some cases, the 40 focal cows were split across multiple pens. To calculate the correlations, we excluded farms for which we were not certain if both sets of measures were taken from the same pens. For correlations with time away for milking, we used only 65 farms for which we had complete data from a single pen. For the correlations involving stocking density, pen population and area per cow, we calculated the mean value for the farm by combining the values for the pens that contained the focal cows, but only if the stocking density in the pens differed by less than $5 \%$ (which could differ greatly from pen to pen). The final correlations involving the pen density measures were based on 73 farms.

To test whether a difference existed in lying time between farms with the shortest (below the median; $<3.3 \mathrm{~h} / \mathrm{d} ; \mathrm{n}=32$ ) and longest (above the median; $\geq 3.3 \mathrm{~h} / \mathrm{d} ; \mathrm{n}=33$ ) milking durations, and to test farms stocking $\leq 100 \%(\mathrm{n}=54)$ or $>100 \%(\mathrm{n}=19)$ of the recommended stocking rate by the Code of Practice, a chi-squared test was used.

To examine whether the effect of milking time was most obvious on farms with a high stocking density, we divided the farms according to whether they were above or below the median for stocking density and recalculated the correlations between the lying time variables and milking time separately for each group. We also recalculated the correlations between stocking density and lying times after classifying the farms as being above or below the median for milking times.

\section{RESULTS}

All of the facility measures varied greatly between farms (Table 2). Of the 111 farms, a majority (60\%) had a stall stocking density $\leq 100 \%$ (i.e., more stalls 
Table 2. Median; 10th, 25th, 75th, and 90th percentiles; and range for stall stocking density, pen population, pen area, area per cow, and milking duration of 164 pens, and for daily duration of lying down, daily frequency of lying bouts, and mean duration of lying bouts on 111 farms

\begin{tabular}{|c|c|c|c|c|c|c|c|}
\hline Item & Minimum & $\begin{array}{c}\text { 10th } \\
\text { percentile }\end{array}$ & $\begin{array}{c}25 \text { th } \\
\text { percentile }\end{array}$ & Median & $\begin{array}{c}\text { 75th } \\
\text { percentile }\end{array}$ & $\begin{array}{c}90 t h \\
\text { percentile }\end{array}$ & Maximum \\
\hline Stall stocking density $\left(\%^{1}\right)$ & 52.2 & 74.4 & 85.6 & 96.2 & 104.0 & 113.3 & 160.0 \\
\hline Pen population (no. of cows) & 8.0 & 32.2 & 40.0 & 60.0 & 93.5 & 117.7 & 300.0 \\
\hline Area/cow $\left(\mathrm{m}^{2}\right)$ & 4.6 & 6.0 & 7.0 & 8.0 & $\begin{array}{r}9.1 \\
9.5\end{array}$ & 11.7 & 15.0 \\
\hline Milking duration $(\mathrm{h} / \mathrm{d})$ & 0.7 & 1.5 & 1.8 & 2.8 & 3.7 & 4.9 & 8.0 \\
\hline Daily duration of lying down $(\mathrm{h} / \mathrm{d})$ & 8.7 & 9.7 & 10.2 & 10.6 & 11.4 & 12.1 & 13.2 \\
\hline
\end{tabular}

${ }^{1}$ Number of cows/number of useable lying stalls $\times 100$.

than cows). One-third of the farms $(33 \%)$ had a stall density between 100 and $120 \%$, and $7 \%$ of farms had a stall stocking density $>120 \%$. Overstocking tended to be more common on farms with more than 1 pen: only $16 \%$ of farms with 1 pen for lactating cows were stocked more than $100 \%$, whereas $58 \%$ of farms with more than 1 pen of cows was stocked $>100 \%$. Time away from the home pen for milking was correlated with the number of cows in the pen [Spearman $\mathrm{r}\left(\mathbf{r}_{\mathrm{s}}\right)=$ $0.45 ; P<0.01]$ but not with stall stocking density $\left(\mathrm{r}_{\mathrm{s}}\right.$ $=0.15 ; P>0.10)$.

Table 2 shows the distribution of the measures of lying time, which also varied greatly across farms. Almost $90 \%$ of the farms had a mean duration of lying time less than $12 \mathrm{~h} / \mathrm{d}$. Table 3 shows the correlations between the measures of lying time and the facility measures. When all pens were considered, stall stocking density did not correlate with any measures of time spent lying down. No correlations were observed between lying time and stocking density when the farms were split into 2 groups as being above or below the median for time away for milking $(P>0.10)$. However, the mean lying time on a farm was not completely independent of the stall stocking density. No farm with stocking density greater than $100 \%$ achieved a mean herd lying duration of $12 \mathrm{~h} / \mathrm{d}$ or higher, whereas $21.6 \%$ of farms with a stocking density of $100 \%$ or less did achieve or exceed that target (Figure $1 ; \chi^{2}=4.86$, df $=1 ; P<0.03)$.

Pen population was positively correlated with the frequency of lying bouts and negatively correlated with the mean duration of lying bouts, irrespective of stocking density (Table 3). The area per cow tended to be negatively correlated with the daily frequency of lying bouts and positively correlated with bout duration (Table 3).

Overall, the more time cows spent away from their home pen while being milked, the shorter the mean duration of their lying bouts (Table 3 ). Some evidence existed that milking time had a larger effect when stocking density was high: the correlation between time away for milking and mean duration of lying bouts was only significant on the farms above the median stocking density $(\mathrm{r}=-0.40 ; P=0.04)$ and not for farms below the median stocking density $(\mathrm{r}=-0.18 ; P>0.10)$. The time away was not correlated with the daily duration of lying (Table 3). However, the relationship between time away from the pen and lying time was not linear. Of the $50 \%$ of farms that were below the median of time away from the pen for milking ( 0.8 to $3.2 \mathrm{~h} / \mathrm{d}$ ), $26.5 \%$ had a mean daily duration of lying time $\geq 12 \mathrm{~h} / \mathrm{d}$, whereas only $6.9 \%$ of the farms that were above the median for time away from the pen $(3.3$ to $8.0 \mathrm{~h} / \mathrm{d})$ did so $\left(\chi^{2}=\right.$ $4.16, \mathrm{df}=1 ; P=0.04)$. In Figure 2 , it is apparent that no farm that had time away from the pen longer than $3.7 \mathrm{~h} / \mathrm{d}$ achieved a mean daily duration of lying time $\geq 12 \mathrm{~h} / \mathrm{d}$. Furthermore, among the $50 \%$ of farms above the median for longest time away from the pen, time away was negatively correlated with daily duration of lying time $\left(\mathrm{r}_{\mathrm{s}}=-0.52 ; P=0.01\right)$, whereas no correlation $\left(\mathrm{r}_{\mathrm{s}}=0.16 ; P>0.10\right)$ existed among the $50 \%$ of farms below the median for time away.

Table 3. Spearman correlation (and $P$-value) between facility-based measures and measures of lying time based on 73 pens ${ }^{1}$

\begin{tabular}{|c|c|c|c|c|c|c|c|c|}
\hline \multirow[b]{2}{*}{ Item } & \multicolumn{2}{|c|}{$\begin{array}{c}\text { Stall stocking } \\
\text { density }(\%)\end{array}$} & \multicolumn{2}{|c|}{ Pen population } & \multicolumn{2}{|c|}{ Area/cow $\left(\mathrm{m}^{2}\right)$} & \multicolumn{2}{|c|}{$\begin{array}{l}\text { Time away } \\
\text { from pen }(\mathrm{h} / \mathrm{d})\end{array}$} \\
\hline & $\mathrm{r}$ & $P$-value & $\mathrm{r}$ & $P$-value & $\mathrm{r}$ & $P$-value & $\mathrm{r}$ & $P$-value \\
\hline Daily frequency of lying bouts & 0.13 & 0.27 & 0.24 & 0.04 & -0.21 & 0.08 & 0.17 & 0.16 \\
\hline Mean duration of lying bouts (h) & -0.18 & 0.12 & -0.30 & 0.01 & 0.20 & 0.09 & -0.27 & 0.02 \\
\hline
\end{tabular}

${ }^{1}$ The averages of lying behavior were used for farms with more than 1 pen where the difference in stocking was $<5 \%$. 


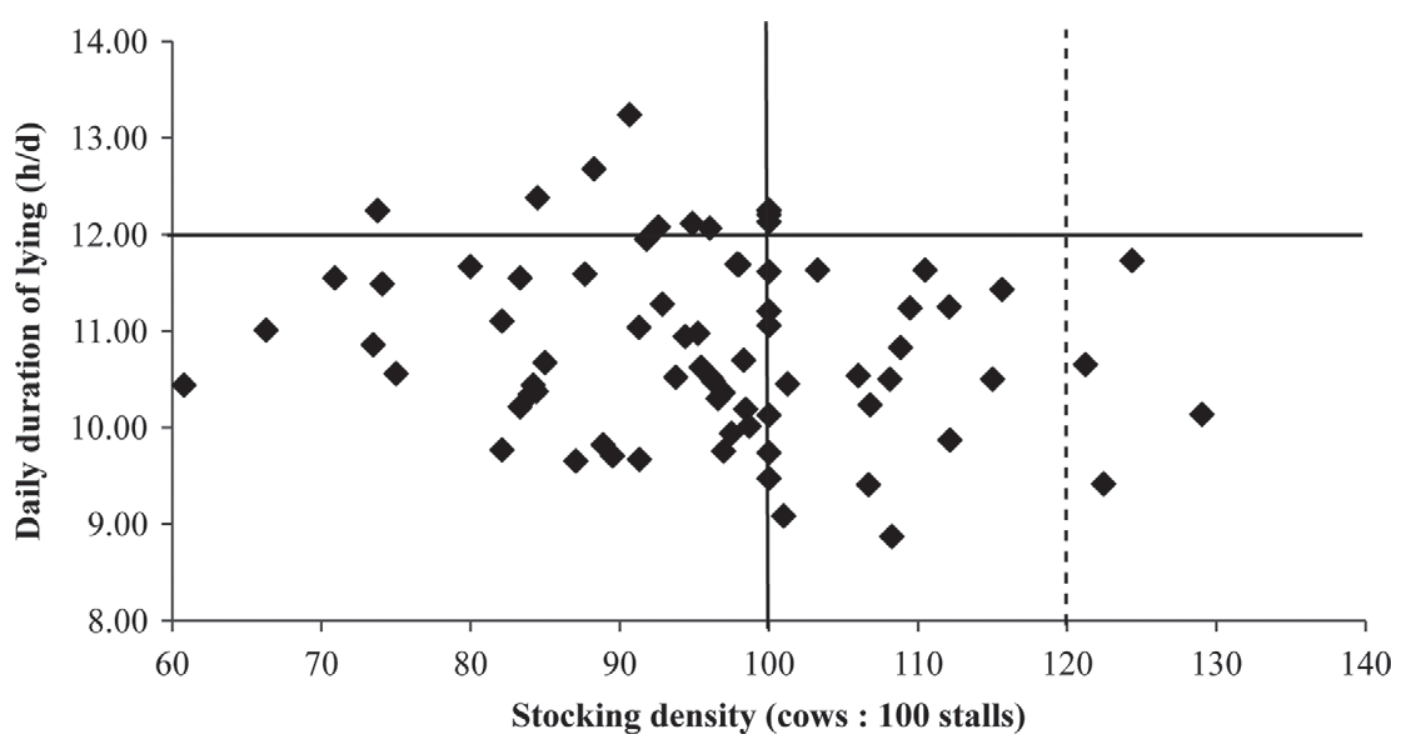

Figure 1. Median daily duration of lying down and stocking density (number of cows per 100 lying stalls). Each point represents a single pen from 73 freestall farms. The average daily duration of lying $(\mathrm{h} / \mathrm{d})$ and stocking density were used for farms with more than 1 pen where the difference in stocking was $<5 \%$. The horizontal line represents the recommended lying time (h/d) for dairy cattle from the Canadian Code of Practice (Dairy Farmers of Canada, 2009) and the vertical lines represent the recommended (solid line) and required (dashed line) stocking density from the Canadian Code of Practice.

\section{DISCUSSION}

Although the effects were not large, we found some evidence that stall stocking density and time away from the pen for milking account for some of the variation between farms in herd mean lying time. A stocking density greater than 1 cow per lying stall and time away from the pen longer than $3.7 \mathrm{~h} / \mathrm{d}$ consistently resulted in herd mean lying times below $12 \mathrm{~h} / \mathrm{d}$, whereas increasing milking duration above $3.3 \mathrm{~h} / \mathrm{d}$ reduced herd mean lying time. We found some evidence that the effects of the time away from the pen for milking were most apparent on farms that were above the median for stocking density.

The herd mean lying time varied considerably from farm to farm, and was similar to that reported previously (Ito et al., 2009; von Keyserlingk et al., 2012; Deming et al., 2013; i.e., a median of between 10 and

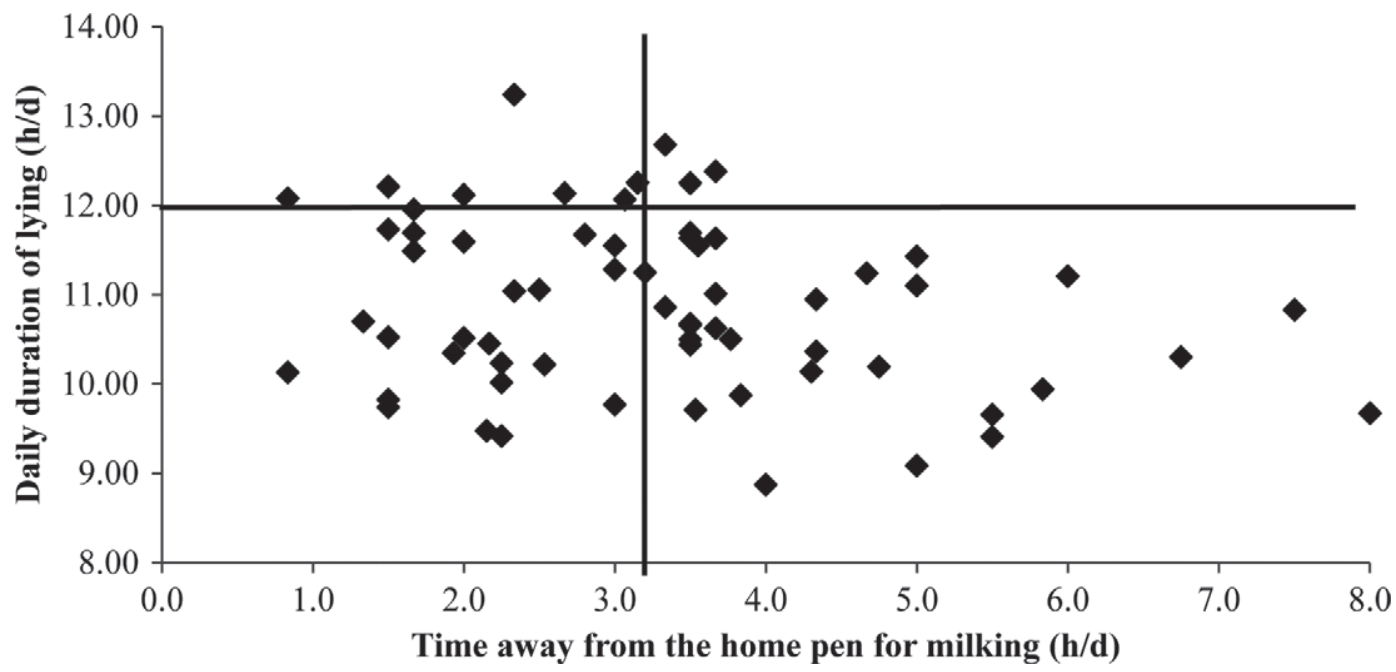

Figure 2. Median daily duration of lying down and time away from the pen for milking. Each point represents a single pen from 65 freestall farms. The average daily duration of lying $(\mathrm{h} / \mathrm{d})$ and time away from the home pen $(\mathrm{h} / \mathrm{d})$ were used for farms with more than 1 pen where the difference in stocking was $<5 \%$. The horizontal line represents the recommended lying time (h/d) for dairy cattle from the Canadian Code of Practice (Dairy Farmers of Canada, 2009), and the vertical line represents the median milking duration. 
$11 \mathrm{~h} / \mathrm{d}$ and a range of 9 to $14 \mathrm{~h} / \mathrm{d}$ ). Thus, the majority of freestall dairy farms in North America do not meet the recommended lying time of $12 \mathrm{~h} / \mathrm{d}$ of the Canadian Code of Practice (Dairy Farmers of Canada, 2009). In the current study, on average, cows lay down 10.5 times per day, which is similar to that found by Gomez and Cook $(2010 ; 11.0$ times/d) and more than that found by Deming et al. (2013; 9.3 times/d). The lying bouts in the current study lasted an average of $72 \mathrm{~min}$, very similar to the duration reported previously (Gomez and Cook, 2010; Deming et al., 2013). However, we found variation between farms in both the frequency of lying bouts and the mean bout duration.

The absence of a strong effect of stocking density on lying time was surprising, given that experimental studies have consistently shown that increases in stocking density reduce the time that cows spend lying down (Fregonesi et al., 2007; Krawczel et al., 2012; Telezhenko et al., 2012). This lack of an effect may reflect the fact that the majority of farms in our study were stocked at less than 1 cow per lying stall and only $7 \%$ were stocked at more than 120 cows per 100 lying stalls. The proportion of farms that had stocking densities greater than $100 \%$ (40\%) was smaller than those reported in the United States and in British Columbia (60\%) by von Keyserlingk et al. (2012), and the great majority of farms (93\%) met or bettered the requirement of the Code of Practice (Dairy Farmers of Canada, 2009). The discrepancy may also reflect that the lying times of the control cows in the small-scale studies were generally higher than the average lying times for the cows in our study (e.g., Fregonesi et al. 2007) and that the experimental studies likely avoided cows with health issues, whereas such cows would have been included in our sample. However, mean farm lying time was not independent of stocking density: it was apparent that no farm stocked at greater than 1 cow per stall was able to achieve the recommended herd mean lying time of 12/d (Dairy Farmers of Canada, 2009).

Consistent with von Keyserlingk et al. (2012), we found that the area available to each cow within the pen varied greatly from farm to farm, from less than 5 to $15 \mathrm{~m}^{2}$ /cow. Farms with more area per cow tended to have fewer and slightly longer bouts of lying but the effects were not statistically significant. The actual number of cows within the pen (irrespective of the area) was more highly correlated with measures of lying time than was the area per cow, with fewer, longer lying bouts occurring where there was a larger number of cows, although the daily lying time was not related to the pen population. The lying time on a farm can also be affected by space at the feed bunk (Deming et al., 2013). Thus, the relationships between pen area, population and the lying time of the cows are complex, with the space allowance per cow, group size, feed bunk space, and ratio of cows to lying stalls all potential factors affecting lying time.

Dairy producers are often advised to minimize the time that cows are out of the pen for milking, with the Canadian Code of Practice recommending a maximum milking time of $1 \mathrm{~h}$. We measured time away from the pen for milking by the time that elapsed from when the first cow left the pen to when the last cow returned. This varied from 0.7 to $8.0 \mathrm{~h} / \mathrm{d}$, consistent with what was found by von Keyserlingk et al. (2012). We found that the time cows were out of the pen for milking had a larger effect on herd mean lying time than any measure of density (number of stalls or overall space), with a critical time being somewhere in the range of 3.3 to $3.7 \mathrm{~h} / \mathrm{d}$. When this measure of time away from the pen for milking was below $3.3 \mathrm{~h} / \mathrm{d}$, no relationship was observed with the herd mean lying time. However, above $3.3 \mathrm{~h} / \mathrm{d}$, an increase in time away from the pen was associated with a reduction in herd mean lying time, with $27 \%$ of the variation between farms in lying time being associated with variance in time away from the pen. Over all farms, an increase in time away was associated with a reduction in the mean bout duration of lying down. Finally, no farm with time away from the pen longer than $3.7 \mathrm{~h} / \mathrm{d}$ achieved the recommended herd mean lying time of $12 \mathrm{~h} / \mathrm{d}$ or longer.

\section{CONCLUSIONS}

Very few Canadian farms stocked at greater than $120 \%$. Stocking density was not significantly related to lying behavior, but farms that stocked at greater than $100 \%$ did not achieve the recommended lying time of $12 \mathrm{~h} / \mathrm{d}$. The time the cows spent away from the home pen being milked also influenced cow comfort, with lying bout duration decreasing with increased time away from the pen. Also, no farms achieved a mean daily duration of lying $\geq 12 \mathrm{~h} / \mathrm{d}$ when cows were kept away from the home pen for $3.7 \mathrm{~h} / \mathrm{d}$ or longer. To increase the chance of cattle achieving the recommended daily lying time of $12 \mathrm{~h} / \mathrm{d}$, the stall stocking density, pen population, and time away from the home pen for milking should be considered.

\section{ACKNOWLEDGMENTS}

This study was funded by Agriculture \& Agri-Food Canada (Ottawa, ON, Canada) and Dairy Farmers of Canada (Ottawa, ON, Canada) as part of the Dairy Science Cluster initiative; le Fonds de recherche du Québec-Nature et technologies (FRQNT)Novalait-ministère de l'Agriculture, des Pêcheries et de l'Alimentation du Québec (MAPAQ)-Agriculture et 
Agroalimentaire Canada (AAC) as part of the partnership program for innovation in dairy production and transformation; Alberta Milk (Edmonton, AB, Canada); and CanWest DHI (Guelph, ON, Canada). We thank the collaborators Dan Weary and Nina Von Keyserlingk (both from the University of British Columbia, Vancouver, BC, Canada), Karin Orsel, Herman Barkema, Ed Pajor, Laura Solano, Guilherme Bond, Steve Mason (University of Calgary, Calgary, AB, Canada), David Kelton, Stephen LeBlanc, Trevor DeVries Jessica Zaffino Heyerhoff, Clemence Nash (University of Guelph, Guelph, ON, Canada), Doris Pellerin and François Becotte (both from Université Laval, Quebec City, QC, Canada), Daniel Lefevbre and Veronique Becotte (both from Valacta Inc., Sainte-Anne-de-Bellevue, QC, Canada), and Jenny Gibbons and Elsa Vasseur (both from Agriculture \& Agri-Food Canada, Agassiz, BC, Canada). We also gratefully acknowledge all dairy producer participants.

\section{REFERENCES}

Bach, A., N. Valls, A. Solans, and T. Torrent. 2008. Associations between nondietary factors and dairy herd performance. J. Dairy Sci. 91:3259-3267.

Bell, N. J., M. J. Bell, T. G. Knowles, H. R. Whay, D. J. Main, and A. J. F. Webster. 2009. The development, implementation and testing of a lameness control programme based on HACCP principles and designed for heifers on dairy farms. Vet. J. 180:178-188.

Botheras, N. A. 2006. The behaviour and welfare of grazing dairy cows (Bos taurus): Effects of time away from pasture and position in the milking order. PhD Thesis. University of Melbourne, Melbourne Australia.

Chapinal, N., A. K. Barrientos, M. A. G. von Keyserlingk, E. Galo, and D. M. Weary. 2013. Herd-level risk factors for lameness in freestall farms in the northeastern United States and California. J. Dairy Sci. 96:318-328.

Chapinal, N., A. M. de Passillé, D. M. Weary, M. A. G. von Keyserlingk, and J. Rushen. 2009. Using gait score, walking speed, and lying behavior to detect hoof lesions in dairy cows. J. Dairy Sci. 92:4365-4374.

Cook, N. B., T. B. Bennett, and K. V. Nordlund. 2004. Effect of free stall surface on daily activity patterns in dairy cows with relevance to lameness prevalence. J. Dairy Sci. 87:2912-2922.

Dairy Farmers of Canada. 2009. Code of Practice for the Care and Handling of Dairy Cattle. Dairy Farmers of Canada, Ottawa, ON, Canada.

Deming, J. A., R. Bergeron, K. E. Leslie, and T. J. DeVries. 2013. Associations of housing, management, milking activity, and standing and lying behavior of dairy cows milked in automatic systems. J. Dairy Sci. 96:344-351.

EFSA (European Food Safety Authority). 2009a. Scientific Opinion of the Panel on Animal Health and Welfare on a request from the Commission on the risk assessment of the impact of housing, nutrition and feeding, management and genetic selection on behaviour, fear and pain in dairy cows. EFSA J. 1139:1-68. EFSA, Parma, Italy.

EFSA (European Food Safety Authority). 2009b. Scientific report of EFSA prepared by the Animal Health and Animal Welfare Unit on the effects of farming systems on dairy cow welfare and disease. Annex to the EFSA Journal. 1143:1-284. EFSA, Parma, Italy.

Fregonesi, J. A., C. B. Tucker, and D. M. Weary. 2007. Overstocking reduces lying time in dairy cows. J. Dairy Sci. 90:3349-3354.

Gomez, A., and N. B. Cook. 2010. Time budgets of lactating dairy cattle in commercial freestall herds. J. Dairy Sci. 93:5772-5781.

Ito, K., D. M. Weary, and M. A. G. von Keyserlingk. 2009. Lying behavior: Assessing within- and between-herd variation in free-stallhoused dairy cows. J. Dairy Sci. 92:4412-4420.

Jensen, M. B., L. J. Pedersen, and L. Munksgaard. 2005. The effect of reward duration on demand functions for rest in dairy heifers and lying requirements as measured by demand functions. Appl. Anim. Behav. Sci. 90:207-217.

Krawczel, P. D., L. B. Klaiber, R. E. Butzler, L. M. Klaiber, H. M. Dann, C. S. Mooney, and R. J. Grant. 2012. Short-term increases in stocking density affect the lying and social behavior, but not the productivity, of lactating Holstein dairy cows. J. Dairy Sci. 95:4298-4308.

Ledgerwood, D. N., C. Winckler, and C. B. Tucker. 2010. Evaluation of data loggers, sampling intervals, and editing techniques for measuring the lying behavior of dairy cattle. J. Dairy Sci. 93:5129-5139.

Metz, J. H. M. 1985. The reaction of cows to a short-term deprivation of lying. Appl. Anim. Behav. Sci. 13:301-307.

Munksgaard, L., M. B. Jensen, L. J. Pedersen, S. W. Hansen, and L. Matthews. 2005. Quantifying behavioural priorities-Effects of time constraints on behaviour of dairy cows, Bos taurus. Appl. Anim. Behav. Sci. 92:3-14.

Munksgaard, L., and H. B. Simonsen. 1996. Behavioral and pituitary adrenal-axis responses of dairy cows to social isolation and deprivation of lying down. J. Anim. Sci. 74:769-778.

Proudfoot, K. L., D. M. Weary, and M. A. G. von Keyserlingk. 2010 Behavior during transition differs for cows diagnosed with claw horn lesions in mid lactation. J. Dairy Sci. 93:3970-3978.

Rushen, J., A. Butterworth, and J. C. Swanson. 2011. Animal Behavior and Well-Being Symposium: Farm animal welfare assurance: Science and application. J. Anim. Sci. 89:1219-1228.

Rushen, J., N. Chapinal, and A. M. de Passillé. 2012. Automated monitoring of behavioural-based animal welfare indicators. Anim. Welf. 21:339-350.

Telezhenko, E., M. A. G. von Keyserlingk, A. Talebi, and D. M. Weary. 2012. Effect of pen size, group size, and stocking density on activity in freestall-housed dairy cows. J. Dairy Sci. 95:3064-3069.

USDA. 2010. Facility characteristics and cow comfort on U.S. dairy operations, 2007. No. 524.1210. USDA-Animal and Plant Health Inspection Service (APHIS)-Veterinary Services (VS), Centers for Epidemiology and Animal Health (CEAH), Fort Collins, CO.

Vasseur, E., J. Rushen, D. Haley, and A. M. de Passillé. 2012. Sampling cows to assess lying time for on-farm animal welfare assessment. J. Dairy Sci. 95:4968-4977.

von Keyserlingk, M. A. G., A. Barrientos, K. Ito, E. Galo, and D. M. Weary. 2012. Benchmarking cow comfort on North American freestall dairies: Lameness, leg injuries, lying time, facility design, and management for high-producing Holstein dairy cows. J. Dairy Sci. 95:7399-7408.

von Keyserlingk, M. A. G., J. Rushen, A. M. de Passillé, and D. M. Weary. 2009. Invited review: The welfare of dairy cattle - Key concepts and the role of science. J. Dairy Sci. 92:4101-4111. 